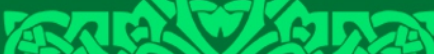
520030102 का 10 4 t

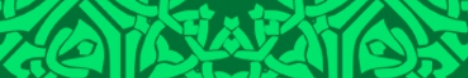
o 21205 रत्र 202 cos (2) 120

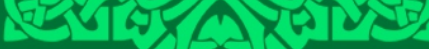
पis 4 कि

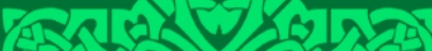
पित 1 (1) 0 (0)

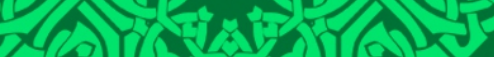
of 2505105 रन्तिए 0 cos 12 an

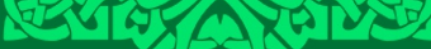
परत w कि Tat

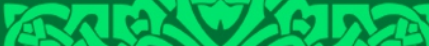
520100103 20 (1) 5 (5)
Sandra Dewi Dahlan, Mirotin Eka Wahyuningsih, Hasbi Assiddiqi, Edi Ardian, Rahmat Fajar The Role of Gossip as a Strategy to Reach Power in Tilik Short Movie

Hasaruddin, Sitti Mania, Ahmad Yani, Musyarif Tracking The Historical Development of Kedatuan Sawitto in South Sulawesi in The XVI-XVII Century

Abdul Muiz Amir, Sahiron Syamsuddin, Siswanto Masruri Dialectic Relationship Between The Qur'an and Hadith: The Interpretation of The Term "As-Sä'Ah" Using Critical Hermeneutic Analysis

Fachmi Alhadar, Safrudin Amin Covid-19 Poems as Cultural Response to Pandemic in Indonesia

Arini Indah Nihayaty, Bagong Suyanto, Sutinah A Study of Religious Symbols Attached to The Former Terrorist Convicts' Family as Seen in Social Interaction Wahyuddin, M. Abdul Hamid محاولات شوقي ضيف التجيديدية في تيسير النحو التعليمي

M. Napis Djuaeni, Hasyim Ashari نظام القافية ودوره في نشأَة المعاجم اللغوية العربية

Hasyim Haddade, Baso Pallawagau, Zaenal Abidin, Muhammad Zakir Husain التجديد في النحو: در اسة مذهب الخطيب الثربيني اللغوي في تفسيره السراج المنير

Nurhakki, Ahmad Sultra Rustan, Muhammad Taufiq Syam The Habituation of Tongkonan Communication as Adhesives for Religious Harmony in Toraja People

Nahdhiyah, Syahruni Junaid A Study of Al Qur'an towards Environmental Issues of Buginese ElongElong (Ecocritical Approach) UNIVERSITAS ISLAM NEGERI ALAUDDIN 


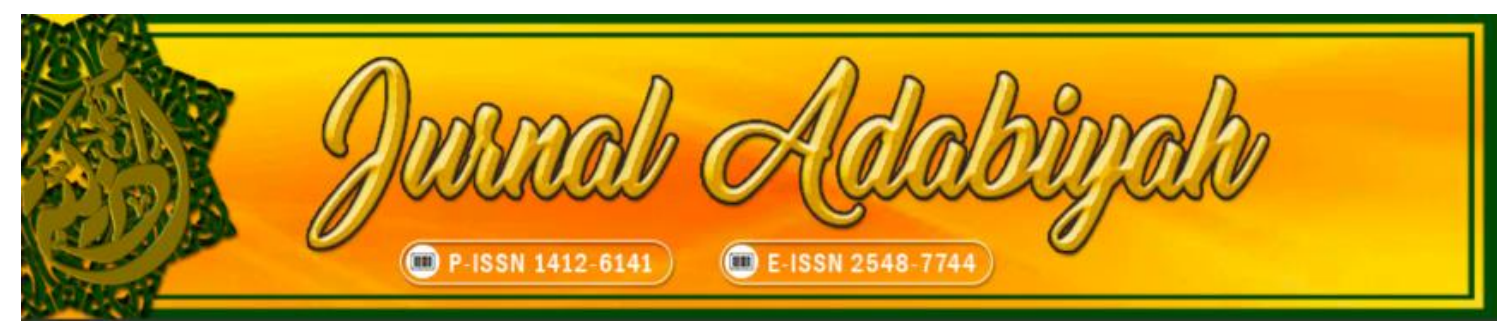

Theme: Humanities

VOLUME 21 NO. 1 JUNE 2021

\section{EDITOR-IN-CHIEF}

Nuri Emmiyati, Alauddin State Islamic University, Indonesia

\section{ASSOCIATE EDITOR}

Barsihannor, Alauddin State Islamic University, Indonesia

\section{INTERNATIONAL EDITORIAL BOARD}

Shamsi Ali, University of Northern California, United States

Miss Tiarne Jade Barratt, University of Sydney, Australia

Muhammad Widus Sempo, Universiti Sains Islam Malaysia, Malaysia

Salih Yousif Sharaf Mohamed, Al-Gazera University, Sudan

Aishah Waenaha Waemamah, Academy of Islamic and Arabic Studies Princess of Naradhiwas University

- Thailand, Thailand

\section{EXECUTIVE EDITOR}

Umar Thamrin, Alauddin State Islamic University, Indonesia

\section{MANAGING EDITOR}

Nasrum, Alauddin State Islamic University, Indonesia

\section{EDITORS}

Akbar Haseng, Institut Agama Islam Negeri Kendari, Indonesia Sardian Maharani Asnur, Alauddin State Islamic University, Indonesia Subehan Khalik Umar, Alauddin State Islamic University, Indonesia

Haniah, Alauddin State Islamic University, Indonesia

Andi Satrianingsih, Universitas Muhammadiyah Makassar, Indonesia

Awaluddin Syamsu, Universitas Muslim Indonesia

Muhammad Azwar, UIN Syarif Hidayatullah Jakarta, Indonesia

\section{ASSISTANT TO THE EDITORS}

Chusnul Chatimah Asmad, Alauddin State Islamic University, Indonesia

ENGLISH LANGUAGE ADVISOR

Rosmah Tami, Alauddin State Islamic University, Indonesia

Syahruni Junaid, Alauddin State Islamic University, Indonesia

\section{ARABIC LANGUAGE ADVISOR}

Muh. Saleh Syamsuri, Alauddin State Islamic University, Indonesia

Baso Pallawagau, Alauddin State Islamic University, Indonesia

\section{IT SUPPORT}

Taufiq Mathar, Alauddin State Islamic University, Indonesia

\section{COVER DESIGNER}

Nur Arifin 


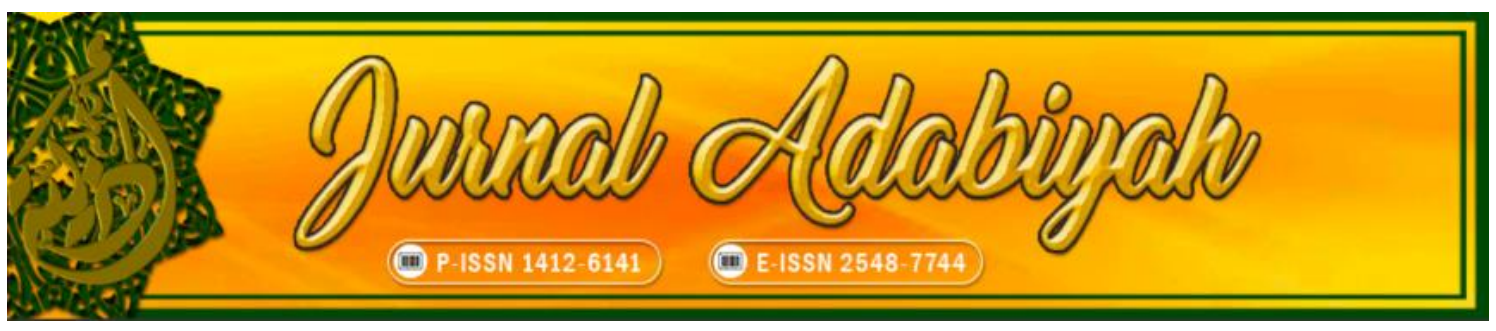

\section{Jurnal Adabiyah:}

This journal receives a national accreditation from Ministry of Research, Technology, and Higher Education Republic of Indonesia, Nomor 10/E/KPT/2019 on April 4, 2019 with the SINTA score: S2.

The Journal has been published by the Faculty of Adab and Humanity of Alauddin State Islamic University, Makassar, since 1997 and has been online since 2016 with the main themes on Humanities and Islamic Studies with the emphasis on interdisciplinary and intertextuality approach.

This journal are published twice a year, on June and December. The themes related to Islamic Studies are textual studies, scriptural traditions, Islamic law, and theology; and those related to Humanities are language, literature, history, and culture.

The journal of Humanities and Islamic Studies will provide the online collection of articles from 1997 up to now. The most updated information can be found on the website. 


\section{Table of Contents}

Besse Wahida, Khaerun Nisa Nuur, Ibnu Hajar Ansori

Tracing Entities of Arabic in The Qur'an

Sandra Dewi Dahlan, Mirotin Eka Wahyuningsih, Hasbi Assiddiqi,

Edi Ardian, Rahmat Fajar

The Role of Gossip as a Strategy to Reach Power in Tilik Short Movie

Hasaruddin, Sitti Mania, Ahmad Yani, Musyarif.

Tracking The Historical Development of Kedatuan Sawitto in South Sulawesi in The XVI-XVII Century

Abdul Muiz Amir, Sahiron Syamsuddin, Siswanto Masruri 57-81

Dialectic Relationship Between The Qur'an and Hadith: The Interpretation of The Term "As-Sā 'Ah" Using Critical Hermeneutic Analysis

Fachmi Alhadar, Safrudin Amin.

Covid-19 Poems as Cultural Response to Pandemic in Indonesia

Arini Indah Nihayaty, Bagong Suyanto, Sutinah

A Study of Religious Symbols Attached to The Former Terrorist Convicts' Family as Seen in Social Interaction

Wahyuddin, M. Abdul Hamid

محاولات شوقي ضيف التجبيليدية في تيسيل النحو الثعليهي

161-187

M. Napis Dj, Hasyim Ashari

نظام القافية ودوره في نشأة المعاجم اللغويا العربية

Hasyim Haddade, Baso Pallawagau, Zaenal Abidin,

Muhammad Zakir Husain

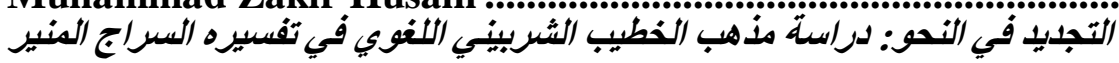

Nurhakki, Ahmad Sultra Rustan, Muhammad Taufiq Syam

The Habituation of Tongkonan Communication as Adhesives for Religious Harmony in Toraja People

Nahdhiyah, Syahruni Junaid

A Study of Al Qur'an towards Environmental Issues of Buginese ElongElong (Ecocritical Approach)

Jurnal Adabiyah Vol 21. Number 1/2021 


\title{
TRACING ENTITIES OF ARABIC IN THE QUR'AN
}

\author{
Besse Wahida ${ }^{1}$, Khaerun Nisa Nuur ${ }^{2}$, Ibnu Hajar Ansori ${ }^{3}$ \\ Institut Agama Islam Negeri Pontianak, Indonesia ${ }^{1}$ \\ Universitas Islam Negeri Alauddin Makassar, Indonesia ${ }^{2}$ \\ Institut Agama Islam Negeri Kediri, Indonesia ${ }^{3}$ \\ Email: bessewahida@iainptk.ac.id ${ }^{1}$, khaerunnisa.nuur@uin-alauddin.ac.id ${ }^{2}$, \\ ibnuhajar93@iainkediri.ac.id ${ }^{3}$
}

\begin{abstract}
This article examined how the Qur'an talks about the Arabic used in it, its essence, existence, and urgency, departing from the dialectic of the foreign languages existence in the Qur'an. This study was library research using an interpretive approach with the method maudū'i which research objects were verses about the Arabic Quran, and were analyzed descriptively. The results showed that the essence of the Arabic language used in the Quran is Arabic which was fluent and clear, which was understood and popular among Arabs when the Qur'an was revealed. The diction used is the word 'arabiy, which is an adjective (sifat) connected to words qur'ān, lisān, and hukman repeated eleven times. The existences of Arabic in the Qur'an are Arabic fuṣhah, Arabic al-Qur'an as Miracle, and Arabic as the language of sharia/law. While the urgency of Arabic use in the Qur'an is seen from the word 'arabiy followed by the word la'alla (لعل) and li (ل) repeated seven times. The repeating means that the urgency of Arabic is the key to understand the Qur'an, encouraging thinking, and encouraging spirituality. The results of this study were expected to be a common thread for the two gro ups arguing about the existence of foreign languages in the Qur'an.
\end{abstract}

Keywords: Arabic; The Qur'an; Entity

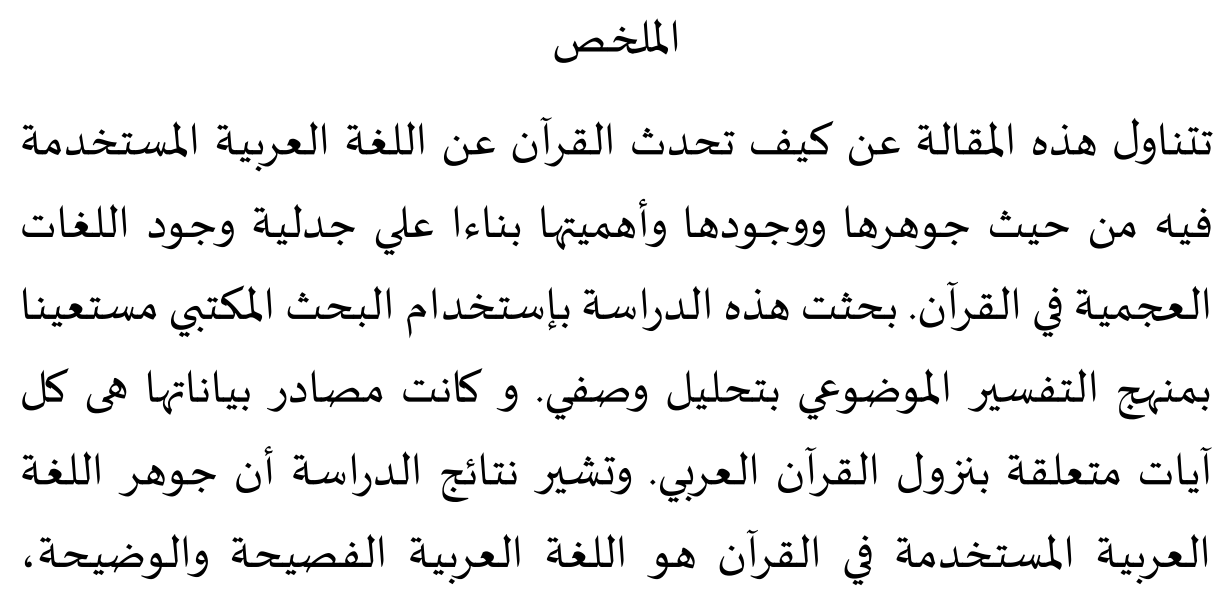




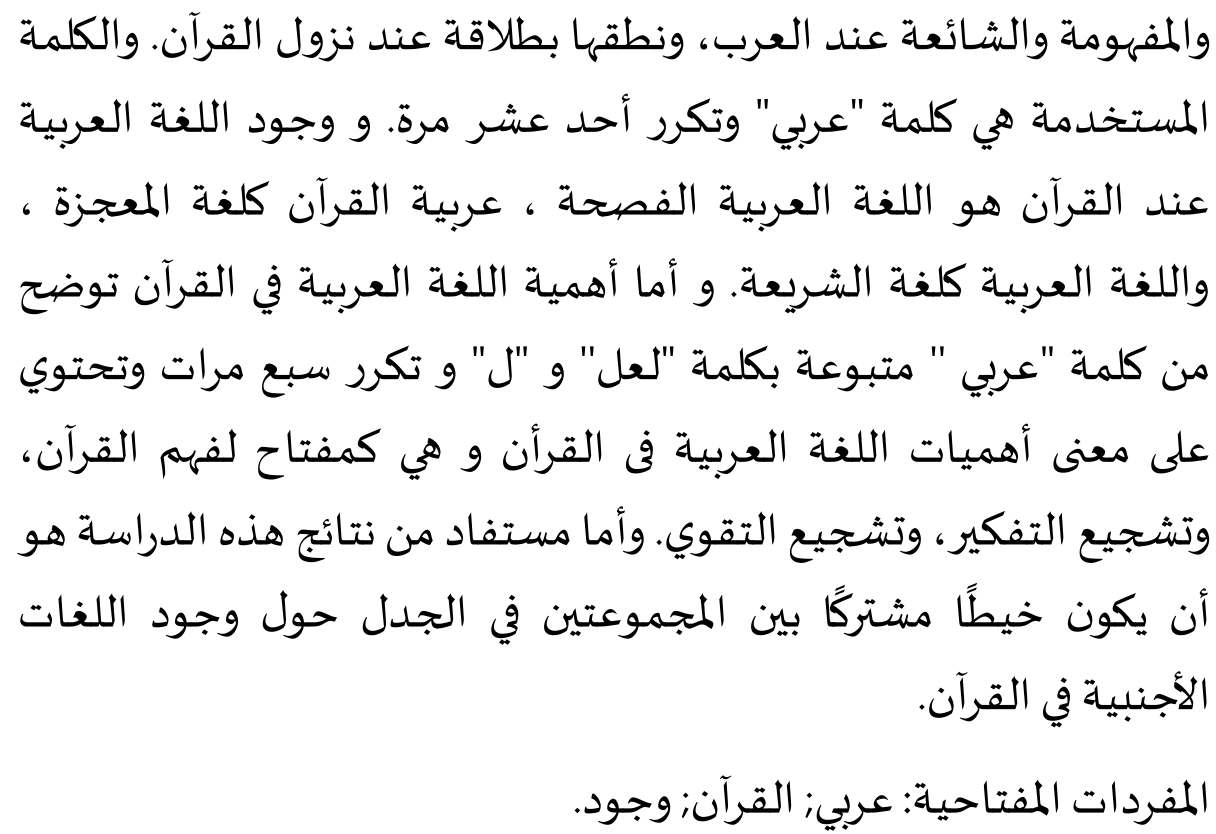

\begin{abstract}
Abstrak
Artikel ini mengkaji bagaimana al-Qur'an berbicara tentang bahasa Arab yang digunakan di dalamnya, baik hakikat, wujud, dan urgensinya, dengan berangkat dari dialektika tentang adanya bahasa Asing dalam al-Qur'an. Kajian ini merupakan penelitian kepustakaan yang menggunakan pendekatan tafsir dengan metode maudū'i yang objek penelitiannya adalah ayat-ayat yang berhubungan dengan diturunkannya al-Qur'an berbahasa Arab, dan dianalisis secara deskriptif. Hasil kajian menunjukkan bahwa hakikat bahasa Arab yang digunakan dalam al-Qur'an adalah bahasa Arab yang fasih dan jelas, yang dipahami dan populer di kalangan bangsa Arab serta dilafazkan secara fasih saat al-Qur'an diturunkan. Diksi yang digunakan adalah kata 'arabiy yang merupakan (sifat) yang terangkai dengan kata qur'ān, lisān, dan hụkman dan berulang sebanyak sebelas kali. Wujud bahasa Arab al-Qur'an yaitu: bahasa Arab fuṣhah, bahasa Arab al-Qur'an sebagai Mukjizat, dan bahasa Arab sebagai bahasa syariat/hukum. Sementara urgensi bahasa Arab digunakan dalam al-Qur'an dilihat dari kata ‘arabiy yang diikuti dengan kata kata la'alla (لعل) dan li (ل) yang terulang sebanyak tujuh kali dan mengandung makna urgensi bahasa Arab yaitu kunci untuk memahami al-Qur'an, mendorong untuk berpikir, dan mendorong spiritualitas. Hasil penelitian ini diharapkan dapat menjadi benang merah bagi dua kelompok yang mempertentangkan mengenai keberadaan bahasa Asing dalam al-Qur'an.
\end{abstract}

Kata Kunci: Bahasa Arab; al-Qur'an; Entitas. 


\section{A. Introduction}

Arabic at first was the language of the Arabs, the nation inhabiting the Arabian jazirah in the Asian continent and the western part of the continent several countries in Northern Africa. After the arrival of Islam, the use of Arabic finally expanded, it was not only the language of Arabs but also became the language of Muslims. It is because that the Qur'an is the holy book derived in Arabic. In the VIIXII century AD, the Arabic language also developed into the language of science along with the development and advancement of Islam. It can be seen from the maturity of the Arabic and the sciences related to it which gave birth to a very high production of Arabic literature, both from the Islamic sciences itself as well as the translation of Greek science and philosophy. Nowadays, Arabic becomes the language of science, especially in islamic studies where the main source is still in Arabic such as the Qur' an and Tafsir.

Arabic is the most important tool in understanding the Qur'an. In the Tafsir studies, Arabic has some urgencies, including knowing the semantic meaning of the verse of the Qur'an and knowing the meaning contained in the verse. ${ }^{1}$ Imam Shafi'i had explained the importance of Arabic for every Muslim who wants to understand the Qur'an, Sunnah and the laws contained in them. He thought that it will be sinful for people who talk about the meaning of the contents of the Qur'an but they do not have extensive knowledge of Arabic. ${ }^{2}$ Therefore, understanding Arabic is essential for anyone who wishes to study, explore, understand, and interpret the Qur'an. ${ }^{3}$

The existence of Arabic as the language of the Qur'an is very clear, Allah mentions in the Qur'an itself, by mentioning the word 'arabiy 11 times and 21 times in other forms of derivation. However, a classical dialectic continues to this day. This, namely the debate about the originality of the language of the Qur'an in Arabic by assuming that the language of the Qur'an was heavily influenced by foreign languages and does not purely use Arabic. Some orientalists who studied the originality of the Arabic language of the Qur'an includes Abraham Geiger (18101874) who stated that the language of the Qur'an was heavily influenced by Jews, ${ }^{4}$ Theodor Noldeke, who mentioned Muhammad's mistake in using the terms of The Aramic language recklessly, ${ }^{5}$ to this decade a national Lebanese, Christoph Luxenberg, claimed that the language of the Qur'an is not Arabic, but was

${ }^{1}$ Musā’id bin Sulaimān Ibnu Nāșir al-Ṭayyâr, Tafsìr al-Lughawi li al-Qur'ān al-Karīm (Arab Saudi: Dār Ibnu Jauzi), p. 2.

${ }^{2}$ Muhammad Idrīs al-Syāfi'i, Al-Risālah, ed. by Ahmad Muhammad Syakir (Beirut: alMaktabah al-'Ilmiyah), p. 84.

${ }^{3}$ Muhammad Idris al-Syāfi'i, Al-Risālah, p. 53.

${ }^{4}$ Andrew Rippin, Introduction to The Qur'an: Style and Contents (Hampshire: Ashgate Publishing Limited, 2001), p.xi.

5 Theodore Noldeke, Sketches from Eastern History, terj. John Suterland Black, M.A. (London: Darft Publishers Limited, 1985), p. 57-58. 
influenced by the Syrian-Aramaic language which caused many words and expressions in the Qur' an to be difficult to understand and often misread. ${ }^{6}$

The opinion of the orientalism who tried to attack the Qur'an from linguistic studies was contradicting the views of classical scholars to contemporary scholars who thought that the language of the Qur'an is pure Arabic, some even called it Quraish, and among them was Imam Shafi'i, Ibn Jarir, al-Tabari, Ibu Faris, and Sya'rawi. This debate inspires the authors to examine how the Qur'an itself explains the language entity by using an interpretive approach with the mau'dhui method (a way of interpreting approach), which is to collect all verses that emphasizes the coming down of the Qur'an in Arabic. This study was conducted to explore the essence and the existence of Arabic used in the Qur'an, as well as the urgency of the Qur'an being revealed in Arabic, in the hope of giving an understanding about the Arabic language entities used in the Qur'an.

\section{B. The Essence of Arabic in The Qur'an}

The use of verses about Arabic in the Qur'an has been researched using the word 'arabun (عرب), and has obtained some words using the word ' arabiy (عربي) and a'rā b أعراب) which is repeated 21 times and found in 15 surahs. $^{7}$ The word 'arabiy 7 times, and majrū r عربي) only once, while the word a'rā b أعراب) repeated 10 times.9

The word 'arabiy (عربي) comes from the word 'Arab عرب) followed by the ratio (yā nisbah) which means the language of Arabs, ${ }^{10}$ namely Arabic. The word is interpreted as the opposite of the word 'ajam, and is also interpreted as the name of the nation, namely the Arabs, namely those who come from villages and inhabit Arab cities or settlement. ${ }^{11}$ It can also mean fluent people, which means

\footnotetext{
${ }^{6}$ Syamsuddin Arif, Al-Qur'an dan Diabolisme Pemikiran (Jakarta: Gema Insani Press, 2007), p. 17.

${ }^{7}$ Muhammad Fuad Abdul Bāqi, Mu’jam al-Mufahras li Alfāz al-Qur'ān al-Kan̄m (Cairo: Dār al-Ḥadīṣ, 2007), p. 456.

${ }^{8}$ The Verses of the Koran That Use the Word 'arabiy are found in Q.S. al-Nahl (16): 103, Asy-Syua'rā (26):195, Yusuf (12): 2, al-Ra'd (13): 37, Tāhā (20): 113, al-Zumar (39): 28, Fushilat (41): 3, Fușilat (41): 44, al-Syūrā (42): 7, al-Zukhruf (43): 3.

${ }^{9}$ The Verses of the Koran That Use the Word al-A'rāb are found in Q.S. al-Taubah (9): 90, 97, 98, 99, 101, 120, al-Ahzāb (33): 20, al-Fath (48):11, dan 16, serta al-Hujurat (49): 14.

${ }^{10}$ Elias A. Elias, Modern Dictionary: Arabic-English (Beirut: Dār al-Jail, 1972), p. 431.

${ }^{11}$ Ibn Al-Manzūur, Lisān al-'Arab (Cairo: Dār al-Ma'ārif, 1119 H), p. 2863-2864.
} 
clear. ${ }^{12}$ In while the word a'rā bu (أعراب), its original form is plural and is a term for the Bedouin. ${ }^{13}$ While in the book Lisān al-'Arab, the word a'rā bu (أعراب) is meant for the Bedouin people descended from the desert, or around the desert, wandering and nomadic. ${ }^{14}$ The whole verses discussing the Arabs use the word a'rābu (أعراب) because it refers to the Bedouin people. In line with what was found in the book of Lisān al-'Arab, Sya'rawiy stated that what is meant by a'rābu (أعراب) in these verses is the Bedouin people who did not live in a place, did not live next door and had no rules in general. They were known for their rudeness and violence. They did not have a society that gathered each other were also very infidels and hypocrites because they were far from a knowledgeable society and $d a$ ' $w a h .{ }^{15}$

They understood that the use of Arabic terms with the word 'arabiyyun (عربي) or 'arabiyyan (عربيا) in the Qur'an is a form of backing or nisbah to the Arabs. Al'Arab العرب is not al-A'rāb means Bedouin. Thus, the Arabic language referred to in the Qur'an is the language used by the nation. Arabs who were fluent in speech and had developed civilization and had an open social culture. The number of verses that discuss about the revelation of the Qur'an in Arabic is 11 verses, and 10 other verses explain the condition of the Arabs Bedouin in the time of the Prophet Muhammad. Here is the version of the eleven verses described as follows:

QS Yusuf /12:2:

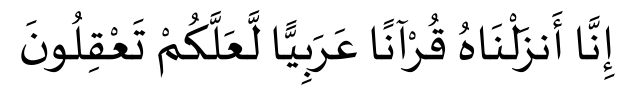

Translation:

"Indeed, We have sent it down as an Arabic Qur'an that you might understand. ${ }^{16}$

${ }^{12}$ Al-Rāgib al-Asfahāni, Mu'jam Mufradāt Alfạaz al-Qur'an (Cet. IV; Damaskus: Dār alQalām, 2009), p. 557.

${ }^{13}$ Al-Rāgib al-Asfahāni, Mu'jam Mufradāt Alfāz Al-Qur'an, p. 556.

${ }^{14}$ Al-Manzūur, Lisān al-'Arab, p. 2863-2864.

${ }^{15}$ Muhammad Mutawalli Al-Sya'rāwi, Tafsìr al-Sya'rāwi (Mutāāi'Akhbār al-Yaūm, 1997), p. 202. http://www.shamela.ws, [accessed 30 Mei 2020].

${ }^{16} \mathrm{https} / / /$ quran.com/12, [accessed 12 June 2020]. 
QS Al-Ra'd/ 13: 37

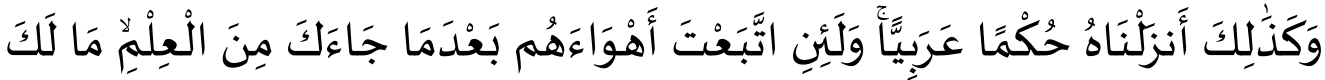

مِنَ اللَّهِ مِن وَلِلِّ وَلَكَ وَاقِ.

Translation:

"And thus, we revealed it as an Arabic legislation. And if you should follow their inclination after what has come to you of knowledge, you would not have against Allah any ally or any protector."17

QS al-Naḥl/ 16:103

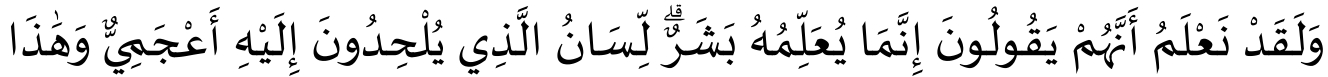

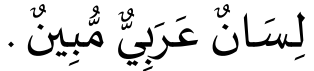

Translation:

"And We certainly that they say, "It is only a human being who teaches the prophet." The tounge of the one they refer to is foreign, and this Qur'an is in a clear Arabic language." 18

QS. T⿳亠̄冖ă/ 20:113

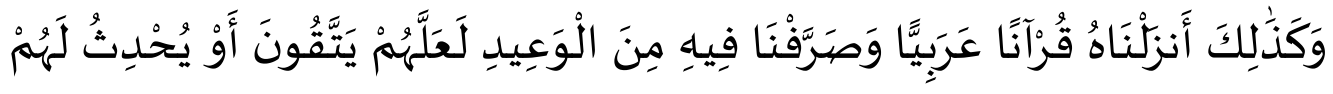

Translation:

"And thus, We have sent it down as an Arabic Qur'an and have diversified therein the warnings that perhaps they will avoid (sin) ir it would cause them rememberance. "19

QS. Asy-Syua'rā/ 26:195

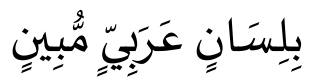

Translation:

"In a clear Arabic language. "º

\footnotetext{
${ }^{17} \mathrm{https}$ //quran.com/13, [accessed 12 June 2020].

${ }^{18} \mathrm{https}$ ://quran.com/16, [accessed 12 June 2020].

${ }^{19} \mathrm{https}$ ://quran.com/20, [accessed 12 June 2020].

${ }^{20} \mathrm{https}$ ://quran.com/26, [accessed 12 June 2020].
} 
QS Al-Zumar/ 39: 27-28

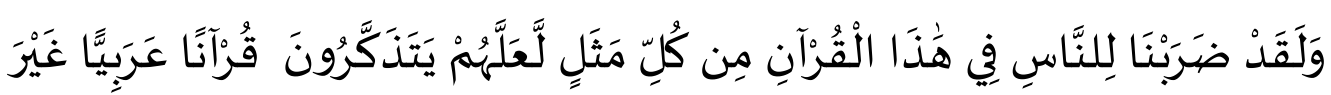
ذِي عِوَجِ لَّعَلَّهُهْ يَتَّقُونَ.

Translation:

"And We have certainly presented for the people in this Qur'an from every (kind of) example - that they might remember. (It is) an Arabic Qur'an, without any deviance that they might become righteous. ${ }^{2} 1$

QS Fushilat/ 41:3

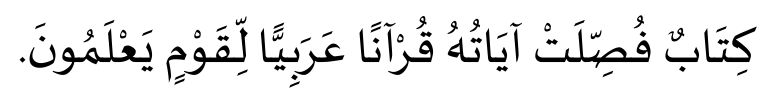

Translation:

"A book whose verses have been detailed, an Arabic Qur'an for a people who know." ${ }^{22}$

QS Fushilat/ 41: 44

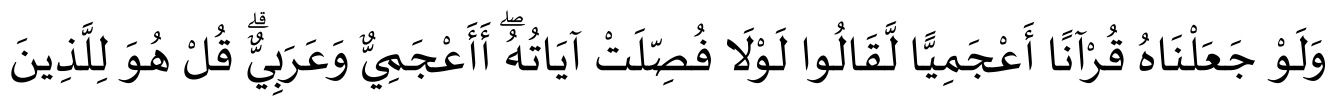

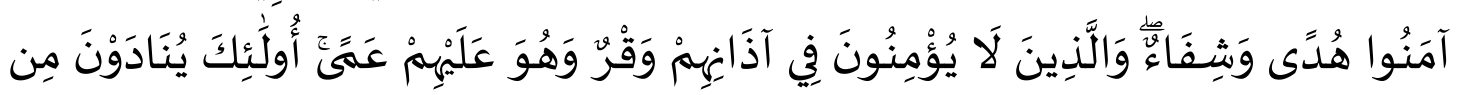

مَّكَانِ بَعِيلٍِ.

Translation:

"And if we had made it non-Arabic Qur'an, they would have said, "why are its verses not explained in detail (in our language)? It is a foreign (recitation) and an Arab (messenger)? "Say, it is, for those who believe, a guidance and cure." And those who do not believe- in their ears is deafness, and it is upon them blindness. Those are being called from a distant place. ${ }^{23}$

QS al-Syūrā/ 42: 7

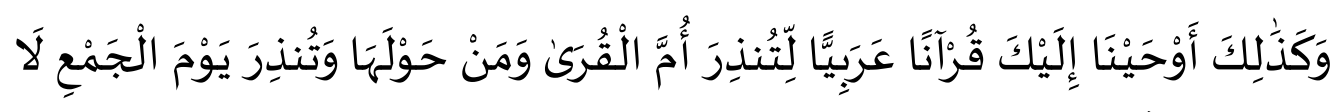

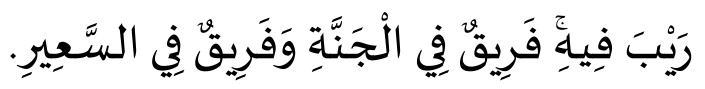

\footnotetext{
${ }^{21} \mathrm{https}$ //quran.com/39, [accessed 12 June 2020].

${ }^{22} \mathrm{https}$ ://quran.com/41, [accessed 12 June 2020].

${ }^{23} \mathrm{https}$ ://quran.com/41, [accessed 12 June 2020].
} 
Translation:

"And thus, We have revealed to you an Arabic Qur'an that you may warn the Mother of Cities [Makkah] and those around it and warn of the Day of Assembly, about which there is no doubt. A party will be in Paradise and a party in the Blaze. "24

QS al-Zukhruf/ 43: 3

$$
\text { إِنَّا جَعَلْنَاهُ قُرْأنَا عَرَبِيَّا لَّعَلَّكُمْ تَعْقِلُونَ. }
$$

Translation:

"Indeed, We have made it an Arabic Qur'an that you might understand."25

QS al-Aḥāq (46): 12

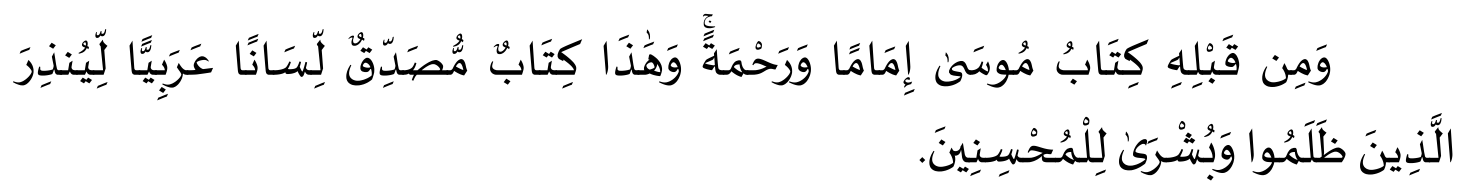

Translation:

"And before it was the scripture of Moses to lead and as a mercy. And this is a confirming Book in an Arabic tongue to warn those who have wronged and as good tidings to the doers of good. "26

Of the eleven verses above, there are three kinds of lafaz that discuss the revelation of the Qur'an in Arabic, namely:

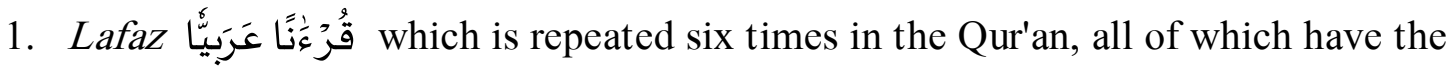
meaning of the Qur'an or readings in Arabic. These verses include: Qur' an Surah Yusuf/12: 2, Surah Thaha/20: 113, Surah Al-Zumar/39: 28, Fussilat/41: 3 dan 44, Surah Al-Syüra/42: 7, and Surah al-Zukhruf/43: 3.

2. Lafaz حُكَمًَا عَرَبِّيًا which is repeated only once with the meaning (Qur'an) as a rule in Arabic, and there were also those who interpreted the rules according to the conditions of the Arabs at that time. This is found in the al-Qur'an Surah al-Ra'd (13): 37 .

3. Lafaz لِّسَنانًا عَرَبِّيًا which is repeated three times, once each with the vowels of fathah, kasrah and damah. The oral is one of the limbs to speak. لسان عربي

\footnotetext{
${ }^{24} \mathrm{https}$ //quran.com/42, [accessed 12 June 2020].

${ }^{25} \mathrm{https}$ ://quran.com/43, [accessed 12 June 2020].

${ }^{26} \mathrm{https}$ ://quran.com/46, [accessed 12 June 2020].

${ }^{27}$ Al-Manzūur, Lisān al- 'Arab, p. 4029.
} 
means whatever is spoken by the Arabs, so it becomes Arabic. ${ }^{28}$ According to Ibn Abbas in Tafsir al-Bagawiy, ${ }^{29}$ the meaning of لسان عربي in the verses of the Qur'an is the language of Quraysh dialect. ${ }^{30}$ The use of this term has a very close meaning to the Arabic term or العربية اللغة as according to al-Sya'rāwi which interpreted the word "oral" in the above verse means the language used, and عربي لسان as the language of Muhammad and the language of the Qur'an which is a clear and obvious Arabic language. ${ }^{31}$

Based on the three expressions in the eleventh verse above, the use of the word 'arabiy which characterizes the words Qur'an̄, hukman, and lisānan clearly shows that the language used by the Qur'an is the Arabic language already used by the nation Arabic at that time both in speaking and in writing fluently and clearly and had been understood by them in the concept and context of the time without any foreign language or any words that they did not understand.

\section{The Existence of Arabic in The Qur'an.}

The form of the Arabic language referred to in the study of tafsir maudu'i is the character of the Arabic language which became the language of the Qur'an. In the 11 verses which present explaining the language of the Qur'an, Allah mentioned that the Qur'an was revealed correctly using Arabic, and the existence of the Arabic language that is implicit and explicit in the eleventh verse is as follows:

\section{Arabic in the Qur'an is Arabic Fluent (Arabic Fushahah)}

The Qur'an is a holy book in which there are rules and instructions of mankind that Allah revealed to Muhammad PBUH through the medium of Jibril as. using Arabic. However, since its arrival, the Qur'an had received many challenges from infidels and polytheists who did not accept the teachings of Muhammad PBUH by launching various accusations against the Qur'an. One of them, they denied the originality of the Qur'an that comes from Allah and considered it as the result of

\footnotetext{
${ }^{28}$ Muhammad Mutawalli al- Sya'rāwi, Tafsìr al-Sya'rāwi, Juz XVII, p. 375. http://www.shamela.ws, [accessed 2 June 2020].

${ }^{29}$ Al-Bagawi quoted Ibn Abbas' opinion in interpreting the above verse because he was one of the interpreters who dominantly used bi al-ma'tsūr interpretation in interpreting Qur'an. He quoted a lot of the prophet's hadis that was limited to hadis sahih only. M. Rusydi Khalid, 'Metodologi Kitab Ma’ālim Al-Tanzill Karya Al-Bagawiy', Adabiyah, vol. 17. no 2 (2017), p. 116.

${ }^{30} \mathrm{Abu}$ Muhammad al-Bagawi, Ma'ālim al-Tanzìl fi Tafsìr al-Qur'an: Tafsir al-Bagawì, Juz III (Beirut: Dār Ihyāa al Turas al-‘Arabiy, 1999), p. 375.

${ }^{31}$ Muhammad Mutawalli al-Sya'rawī, Tafsìr Al-Sya’rāwiy, Juz XIII, p. 8226. http://www.shamela.ws, [accessed 2 June 2020].
} 
Muhammad's creation which he learned from one of the 'ajam. This can be seen on the words of Allah SWT in QS al-Nahl/ 16: 103.

The verse was revealed in connection with the accusation of the infidels who thought that Muhammad had studied the Qur'an from two Christians named Yasar and Jabrun. While the two were reading a book in their language, Rasulullah closed to them and heard their reading. So, they, the infidels and the polytheists, said that Muhammad had learned from both. ${ }^{32}$ Allah Almighty mentioned the lies of those who accused Muhammad PBUH. of having a verbal or language 'ajam and they tended that Muhammad knew the language of 'Ajam, and had learned the Qur'an

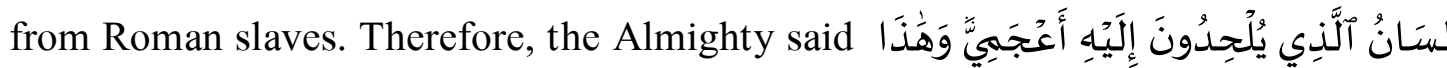

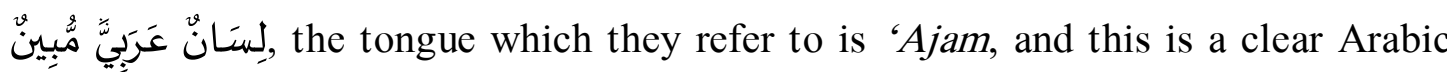
which is the language of Quran. ${ }^{33}$ The meaning of this verse is that they were people who denied the prophet hood of Muhammad PBUH, and that was why they said the Qur'an was taken and learned from others. ${ }^{34}$

Basically, the reason for the revelation of QS al-Nah 1/ 16: 103, was that Allah objected to the existence of the Qur'an came from the results of Muhammad's study of 'Ajam, but on the other hand Allah emphasized that the Qur' an which was accused really used Arabic, while the persons accused of teaching Muhammad alQur'an were Romans or 'ajam. Until the existence of the Qur'an itself in Arabic became a protest against the accusations of infidels and polytheists.

Furthermore, the originality of the Qur'an in terms of language was also attacked by orientalists who thought that the language of the Qur'an was not purely Arabic but had been influenced by Hebrew, Aramaic, Syriac, and was considered to had adopted many terms from previous religions such as Jews and Christians. ${ }^{35}$ Many vocabularies that came from out of Arabic language were mentioned in their works and were used as the excuse that the Qur'an was not original and of course this contradicts the verses of the Qur'an which state that the Qur'an derived in Arabic.

Al-Suyū ti on his book al-Itqā $n$ and al-Muhażżab fí mā Waqa'a fi al-Qur'an min al-Mu'arrab expressed the opinions of scholars regarding the existence of foreign languages in the Qur'an. Imam Syafi'I, Abu Ubaydah, Ibnu Jarir al-Tabā rí, and Ibn Faris rejected the form of foreign vocabulary in the Qur' an because the Qur'an was

\footnotetext{
${ }^{32}$ Abu Hasan 'Āli bin Ahmad Al-Naisabūri, Asbāb Nuzūl al-Qur'ān (Cet. III ; Dār al-Islāh, 1992), p. 281.

${ }^{33}$ Abu Ja'far Al-Ṭabāìi, Jāmi' Al-Bayān fì Ta'wìl al-Qur'ān, Juz XVII (Muassasah al-Risālah, 2000), p. 298 .

${ }^{34}$ Fakhruddin Al-Rāzi, Mafătih al-Gaib, Juz XX (Beirut: Dār Ihyāa al-Turās̀ al-`Arabi), p. 271.

${ }^{35}$ Abraham Geiger (1810) mention in the article "Was hat Mohammed Aus Dem Jdenthume Aufgenommen? (What Muhammad has borrowed from the Jews?) some vocabulary derived from Hebrew such as: Tabüt, taurat, Jannah, Jahannam, Akhbar, Thāgut, Ma'ün, Malaküt. Andrew Rippin, Introduction to The Qur'an: Style and Contents, p. xi.
} 
revealed in Arabic. ${ }^{36}$ Imam Syafi'i also refused to mix foreign languages in the Qur' $a n^{37}$ because it was clear that the Qur' an was revealed in clear Arabic.

According to Sya'rawi, the orientalists did not pay attention to the fact that the Arabs had received various words from a number of other nations as a result of mingeling with these nations. Then these words were pronounced by the Arabic tongue, and the words became Arabic. Even in modern era, there is a word Arabization of the word, and it is absorbed into Arabic and is used as a language or spoken Arabic as long as its meaning is understood. ${ }^{38}$

The word lisān 'Arabiy (لسان عربي) contained in QS al-Nah!̣/16: 103 and confirmed in QS al Syua'rā/26: 195 contains meaning whatever word was spoken by the Arabs because it was pronounced by them, it became Arabic. As for those originating from other languages, what is meant here are words that were not new and unknown to the Arabs, but when the Qur'an came down these words were already popular in the mouth of the Arabs and classified in Arabic. The Qur'an came down using Arabic because the Arabs was a people who received preaching and brought it to other nations, so they must understand the Qur'an. ${ }^{39}$

Arabic contact with other languages took place long before the Qur'an was revealed. Because the reality of a language will continue to evolve following the contacts of culture and civilization in time. By the time of the Prophet, such language contact had occurred in the Arab society used in daily life, especially in Arab art and literature festivals that brought together various tribes of the Arabs, and business activities that brought together the Arabs with other nations such as Persians and Romans. Then, when the Qur'an was revealed, the Arabic language that developed at that time was used by Allah as the language to convey the message of revelation through the Prophet Muhammad PBUH. The language used by the Qur'an is the language used by the Arab community at that time, so it is not wrong for the scholars to reject the existence of a foreign language in the Qur'an, because for them the language was spoken and known among the Arabs at that time, and had been understood by the Arabs.

Another verse that shows the reason that the Qur'an is in Arabic and does not use the language of 'Ajam because it was delivered by Muhammad who was an Arab and would surely invite protest from among the infidels if revealed in a language other than Arabic, namely the word of Allah in QS al-Fussilat/41: 44. Allah sent down the Qur'an in clear Arabic to Muhammad and his people, the Arabs, adapted to

\footnotetext{
${ }^{36}$ Jalāl al-Dīn 'Abd al-Raḥmān Ibn Abī Bakr al-Suyūṭi, al-Itqān fi 'Ulūm al-Qur'ān (Beirut: Dār al-Kitāb al-'Arabiy, 2003), p. 393.

${ }^{37}$ Muhammad Idrìs al-Syāfi'i, al-Risālah, p. 42-50.

${ }^{38}$ Muhammad Mutawalli al-Sya'rāwi Tafsìr Al-Sya'rāwi, Juz XI, p. 8224. http://www.shamela.ws, [accessed 2 June 2020].

${ }^{39}$ Muhammad Mutawalli al- Sya'rāwi, Tafsìr Al-Sya'rāwi, Juz XI, p. 10692. http://www.shamela.ws, [accessed 2 June 2020].
} 
the people to whom communication was communicated where Allah made it a medium of communication to convey His revelation so that they could easily understand it. As Allah SWT says in QS. Ibrahim / 14: 4.

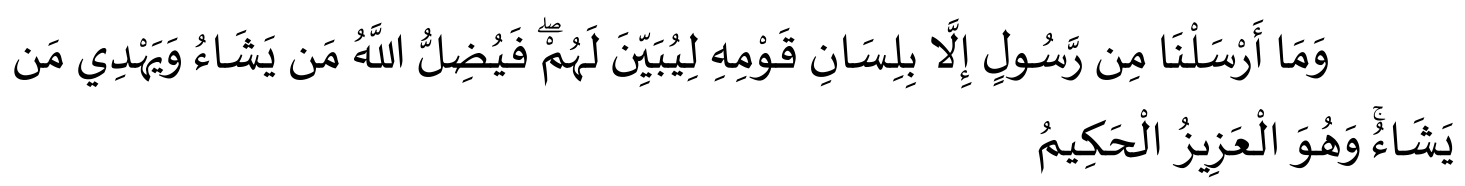

Translation:

"And We did not send any messenger except [speaking] in the language of his people to state clearly for them, and Allah sends astray [thereby] whom He wills and guides whom He wills. And He is the Exalted in Might, the Wise."

This is one of the gentlenesses of Allah to His creatures that He sent to them messenger from among themselves who spoke the same language as them so that they could understand the messenger and understand the message brought by the messenger. ${ }^{41}$ So that there is no reason for them to say they do not understand and know the meaning because the language of the Qur'an is the language of their people. Allah SWT. said in QS Yusuf / 12: 2 and QS al-Fusssilat / 41: 3 which contains the meaning that we (Allah) sent down the Book of the Qur'an in your language (Arabic) so that you learn its meaning, and understand its contents. ${ }^{42}$

In this regard, Imam Ahmad said:

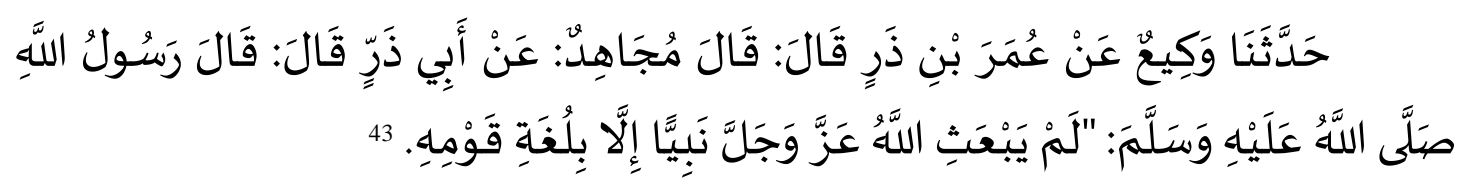

Translation:

'Has told us Waki', from Umar ibnu Zar who said that Mujahid had narrated from Abu Zar that Rasulullah PBUH. once said: There is no Allah SWT. sent a prophet but in the language of his people."

Thus, it is very clear that the reason Allah sent down the Qur'an in Arabic because Muhammad was an Arabian and was sent to people who speak Arabic. The Arabic language referred to here was the language used fluently and correctly and had been understood by all tribes of the Arab nation when the Qur'an was revealed. This language is none other than Arabic fushah which had become the lingua franca

${ }^{40} \mathrm{https}: / /$ quran.com/14, [accessed 12 June 2020].

${ }^{41} \mathrm{Abu}$ al-FaḍāI Ismā'il bin Umar bin Kas̄ìr, Tafsir al-Qur'an al-'Aẓim, Juz IV (Cet. II; Dār Ṭayibah li al-Nasyr wa al-Tauzi', 1999), p. 477.

${ }^{42} \mathrm{Abu}$ Muhammad Husain bin Mas'ud al-Bagāwī, Ma'ālim al-Tanzīl fì Tafsìr al-Qur'an: Tafsìr al-Bagāwīi, Juz IV (Beirut: Dār Ihyā al-Turä̀̄ al-'Arabi), p. 209.

${ }^{43} \mathrm{Abu}$ Abdullah Ahmad bin Muhammad bin Hanbal, 'Musnad Al-Imam Ahmad Bin Hanbal, Juz XXXV (Muassasah Risālah, 2001), p. 323. http://www.shamela.ws, accessed 3 June 2020. 
among the Arabic nation before the Qur'an was revealed. So that the dispute about whether or not there is a foreign language in the Qur'an should be a study of the history of Arabic because Arabic fushah with its predicate as a unifying language has the answer through its long history.

\section{The Arabic of the Qur'an as a miracle}

The miracle is a privilege that Allah gave to the messengers who were tasked with carrying His message which required the value of a challenge to something that the people who were intended to be proud of and praised. Like the miracle of the Qur'an, it was presented to challenge the Arabs, who at that time were a very advanced and superior nation in literary works, and highly adored their poetry and poets. They were a nation that was fluent and had a high style of language. Therefore, Allah made one of the miracles of the Qur'an lies in the language aspects; literature, balaghah $h^{44}$, fasăhah $h^{45}, u s l \bar{u} b^{46}$ and a series of sentences.

Arabic has a beauty and language style that no other language has. Sayyid Qutub pointed out that the attractiveness of the Qur'an that caught the attention of them, the Arabs, since the beginning of its revelation, was not in the sharia that was carried or contained in the verses of the Qur'an, but the beauty of the language that became its attraction. ${ }^{47}$ If we look at the early history of Islam at the time of the Companions, not a few Arabs became melted when they heard the chanting of the verses of the Qur'an. Among those whose hearts were touched was Umar bin alKhatțāb and al-Wālid bin al-Mughïrah who eventually embraced Islam because of listening to the recitation of the holy verses of the Qur'an. ${ }^{48}$ Their hearts melted and were amazed at the strands of Arabic words and its uslubs used in the Qur' an.

In Surah al-Zukruf / 43: 3, Allah swt. said:

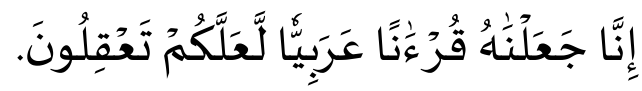

Translation:

"Indeed, We have made it an Arabic Qur'an that you might understand."

\footnotetext{
${ }^{44}$ It means comformity between expression that is stated and the condition or situation accompanied by high fluency. Aḥmad al-Hāsyimī, Jawāhir al-Balāgah fĩ al-Ma'ānī, wa al-Bayāni, wa al-Badi'i (Jakarta: Maktabah Dār Ihyā al-Kutub al-’ Arabiyyah, 1960), h. 31.

${ }^{45}$ Fasahah is the clear word (clear meaning), easy to understand, and many prevailed among writers and poets.Ạ̣mad al-Hāsyimī, Jawāhir al-Balāgah fí al-Ma'ānī, wa al-Bayāni, wa al-Badì'i, h. 7 .

${ }^{46}$ Uslüb means style of sectence. It also means methods to compose sentences. Muhammad 'Abd al-'Aẓim al-Zarqānī, Manāhil al-'Irfān fī 'Ulūm al-Qur'an (Mesir: Dār al-Iḥyā), h. 198.

${ }^{47}$ Sayyid Qutub, Taswir al-Fanny fî al-Qur'ān (Beirut: Dār al Syurūq, t.th), p. 36.

${ }^{48}$ Ibrāhīm Muhammad al-Ḍad, Muhādharāt fì Tārikh al-Adab al-'Arabī 'Ashr Șadri al-Islām (Cairo: Jāmi’at Al-Azhar, 2004), p. 15.
} 
This verse contains the meaning that We (Allah) have made the reading of this Book in Arabic. ${ }^{49}$ According to al-Zamakhsyari, the third verse of this surah alZukhruf is a form of al-qasam's answer from Allah's oath in the previous verse, QS al-Zukruf / 43: 1-2.50

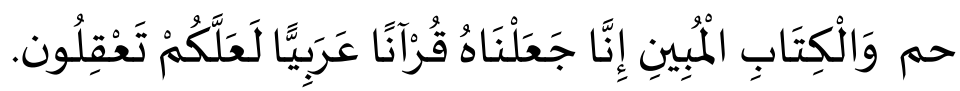

Translation:

"Ha Mim. By the clear book."

The above verse was narrated that I (Allah) swore by a clear book explaining that indeed we had made it the Qur'an in Arabic. According to Ahmad that what made an oath because of the glory or privilege, then made what was sworn is the glory of the Qur'an because the Qur'an is in Arabic and it is hoped that intelligent people can understand it. ${ }^{51}$ Because of the glory of the Qur'an, which uses Arabic clearly, fluently, and the composition of the uslub, Allah made it a Mu'jizat.

Al-Qur'an is a reading in Arabic, because the Messenger of Allah will did preaching among the Arabs, and there must be a miracle that showed the truth of God's style of language and was one that surpasses the Arabic language. For miracles were conditional on challenges, it was impossible to challenge them on things that had no relation with them. Arabs were intelligent people and fluent in language, literature, and poetry. They gathered in the bazaars and boasted of each other on their tribes with the poetry and speech of the poets, and there were literary competitions and had the opportunity to challenge each other and be watched by judges. It all means that they were language trained, sustainable, and judged by people in the market, they were a nation that was fluent and had a style of language in language. Therefore, Allah's will made the Qur'an a miracle of what the Arabs loved. ${ }^{52}$

However, the miracle of the Qur'an is not the only one in terms of language fluency and the beauty of the style it has, but the content of the Qur'an is also very impressive, all packed in a mesmerizing language style so it is not surprising that many embraced Islam after hearing the recitation of the Qur'an. Allah challenged the Arabs to bring something similar to the Qur'an, as Allah said in the Qur'an Surah alIsra '(17): 88.

\footnotetext{
${ }^{49}$ Abu Muhammad Husain bin Mas'ud al-Bagāwì, Ma'ālim al-Tanzìl fî̀ Tafsìr al-Qur'an: Tafsìr al-Bagāwì, Juz IV, p. 154.

${ }^{50} \mathrm{Abu}$ al-Qāsim Maḥmūd Ibn Amr ibn Aḥmad al-Zamakhsyarī, al-Kasysyāf 'an Haqāiq Gawāmị̣ al-Tanzīl, Juz IV (Beirut: Dār al-Kutub al-‘Árabi, 1986), p. 235.

51 Al-Zamakhsyarì, Abu al-Qāsim Mahmūd Ibn Amr ibn Aḥmad Al-Zamakhsyarī, alKasysyāf 'an Haqāiq Gawāmị̣ al-Tanzìl, p. 235.

${ }^{52}$ Muhammad Mutawalli al-Sya'rāwi, Tafsìir al-Sya'rāwi, Juz XI, p. 6824. http://www.shamela.ws, [accessed 3 June 2020].
} 


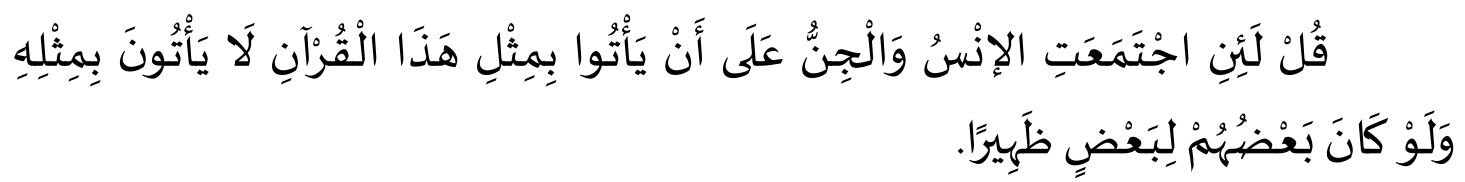

Translation:

"Say, "If mankind and the jinn gathered in order to produce the like of this Qur'an, they could not produce the like of it, even if they were to each other assistants. ${ }^{53}$

Muhammad was sent with an al-Qur'an that is different from the holy book of the previous messengers, because al-Qur'an is a holy book and a miracle at the same time, while the miracles of the previous messengers were separated from the holy book as a guide that was revealed to them. The Qur'an remains a miracle that carries its rules until the Day of Judgment, and as long as people first believe in it and then get lost in the world, so that Allah realized what He promised that this book is complete, will attract the attention of all those who do not believe it becomes enchanted with the rules that are in it. ${ }^{54}$ As for among the miracles of the Qur'an are: ${ }^{55}$

a. The word structure and sentences of the al-Qur'an

Before someone is amazed by the miraculous content of the messages in the Qur'an, the first things that will amaze people who listen to the Qur'an are 1). Tone and style. The English scholar Marmaduke Pictkthall wrote that the Qur'an has an incomparable symphony in which every note can make people cry and rejoice. One example is in al-Qur'an Surah al-Nà zi'à t (79): 1-14

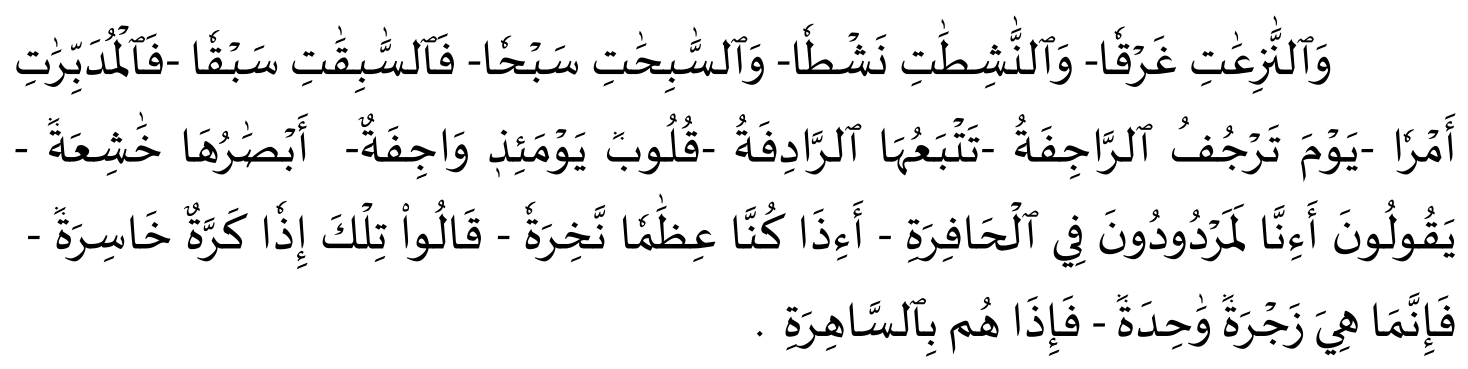

Apart from that, 2). Short and concise. Al-Qur'an has the privilege of being short but has many meanings. 3) Satisfying mind and soul. 4) Satisfying thinkers and the crowd. 5) Having beauty and accuracy of meaning.

b. The balance of the al-Qur'an editorial, namely the balance between the number of words and their antonyms, such as the word al-hayät and the word al-maüt each

\footnotetext{
${ }^{53} \mathrm{https}$ //quran.com/17/80-90, accessed 12 June 2020.

${ }^{54}$ Muhammad Mutawalli al-Sya'rāwi, Tafsìr al-Sya'rāwi, Juz XI, p. 2826. http://www.shamela.ws, [accessed 3 June 2020].

${ }^{55}$ M. Quraish Shihab, Mukjizat al-Qur'an (Mizan Pustaka, 1997), p. 122-148.
} 
repeated 145 times, the words al-har and al-bard respectively each repeated 4 times, and many other words. Also, the balance between the number of words with synonyms or the words they contain, such as the words al-hars and al-ziräat each repeated 14 times, the word al-Qur'an, al-wahyu, and al-Isläm each repeated 70 times and there are many others. Furthermore, namely the balance between the number of words with the number of words that refer to the result, such as the words al-käfirūn and al-När repeated 154 times, the words al-zakät and al-barakât respectively repeats 32 times. The balance between the number of words with the word that causes them, such as the words al-mau'iz at and al-lisān repeated 25 times and so on. As well as special balances such as the word al-yaum being repeated as many days in a year, namely 365 times, the word al-ayyām in the plural form repeated as many days in a month, namely 30 times, and the word syahru-asyhur repeated according to the number of months, namely 12 times.

Those are some examples of miracles of the Qur'an from the linguistic aspect mentioned by Quraish Shihab which showed that the Arabic language of the Qur'an is very rich with $u s l \bar{u} b$, and high literary value so that poets amazed when listening to the beauty of the language. The presence of the Al-Qur'an in Arabic finally added to the wealth of Arabic literature and gave new colors to the characteristics and themes of literature that was developing among the Arabs at that time.

\section{Arabic as the language of Sharia/Law (حكما عربيا)}

Allah SWT said in the Quran Surah al-Ra'd/13: 37.

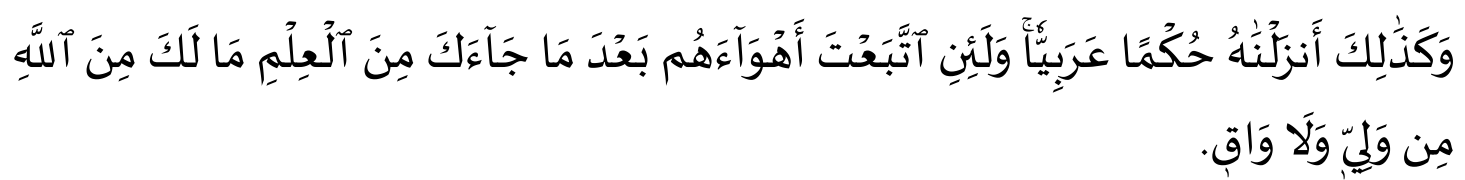

Translation:

"And thus we revealed it as an Arabic legislation. And if you should follow their inclination after what has come to you of knowledge, you would not have against Allah any ally or any protector. ${ }^{56}$

The word a'rabiyyan (عربيا) is the explanatory adjective of the word hukman because the rule was revealed to Muhammad and he was an Arab, so that

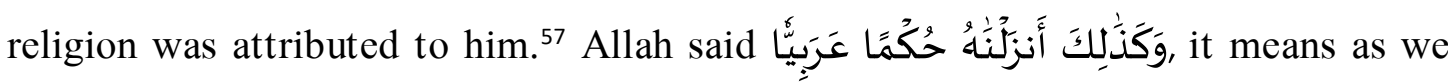
have sent before you the messengers whom we sent down to him the books, we also sent down upon you the Qur'an with your language and the language of the people to make it easier for them to understand its meaning. And the Qur'an is referred to as

\footnotetext{
${ }^{56} \mathrm{https}$ //quran.com/13, [accessed 12 June 2020].

${ }^{57}$ Abu Ja'far al-Ṭabāīi, Jāmi' al-Bayān fì Ta'wìl al-Qur'ān, Juz XXI, p. 475.
} 
the law, meaning to discuss matters that are right because in it is the explanation of halal-haram and everything that is needed to obtain happiness in this world and the hereafter. Then the people of Mecca called to things that denied its contents, and

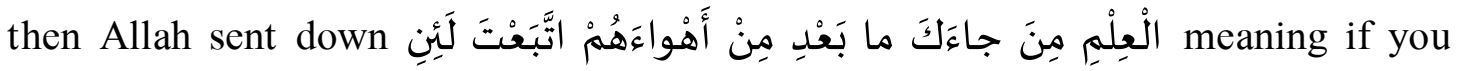
follow the lusts of their group and seek pleasure in them and seek pleasure. Thus, No one but Allah can be your helper. ${ }^{58}$

Thus, the coming down of the Arabic-language Qur' an which contained rules and laws regarding the problems of life faced by the Arabians at that time made them understand and admire the rules that saved them from their problems, even though some groups denied and didn't accept it. Meanwhile, non-Arabians who have accepted the Qur'an as a way of living, a straight life, need to understand very well Arabic as the language of law and sharia, which potentially lead to differences in understanding the text of these rules and laws because of the socio-cultural differences between Arabs and non-Arabs.

\section{The Urgency of Arabic as The Language of The Qur'an}

The existence of the Qur'an in Arabic makes Arabic a special and urgent language for Muslims. More than that, the coming down of the Al-Qur'an in Arabic certainly has a special urgency for mankind apart from its existence as the language of Muhammad, an Arabic messenger. Some urgencies of the Qur'an using Arabic عربي cannot be separated from lafaz of the verses in the Qur' an which make the word as a adjective (sifat) from the word ḥukm (حكم)), Qur'ān (قرأن) and the word lisān (لسان), thus lead to an inseparable unity of meaning. The researchers consider that the word قرأنا is coupled with the word عربيا six times, coupled with the word حكما three times, ${ }^{60}$ dan kata which is coupled with the word عربيا once61 must have had a special meaning. From eleven words in the Qur'an, six of them are linked with the word لعل which means hope (الرجاء).62 It signifies as an intention desired by the owner of the message to the recipient of the message.

\footnotetext{
${ }^{58}$ Ahmad bin Muṣtafā al-Marāgī, Tafsìr al-Marāgi, Juz XIII (Muṣtafā al-Bābī al-Ḥalbī wa Aulāduhū bi Misrr, 1946), p. 113.

${ }^{59}$ Muhammad Fuad Abdul Bāqi, Mu’jam al-Mufahras li Alfäz al-Qur'ān al-Kañm, p. 539540.

${ }^{60}$ Muhammad Fuad Abdul Bāqi, Mu’jam al-Mufahras li Alfäz al-Qur'ān al-Kan̄m, p. 647.

${ }^{61}$ Muhammad Fuad Abdul Bāqi, Mu’jam al-Mufahras li Alfäz al-Qur'ān al-Kan̄m, p. 213.

${ }^{62}$ Abu Ja'far al-Naḥhas, I'rab al-Qur'ān, Juz II (Beirut: Dār al-Kutub al-'Ilmiyyah, 2000), p. 189.
} 
As for some of the urgency of using Arabic as mentioned in the Qur'an, they are as follows:

\section{Arabic as the key to understand the Qur'an (لقَوْم يَعْلَمُونَ)}

The Word of Allah swt in QS al-Fușsilat/41: 3 states that the Qur'an is a book that explains the verses, namely reading in Arabic, for the people who know. It means that the verses of the Qur'an are explained perfectly, the meanings and laws are well detailed. The Arabic-language Qur'an will be easy to understand for people who understand Arabic. ${ }^{63}$

Lafaz لََوُم يَعَلَمُونَ in this verse means people who know many things, rationalize the evidence, and pay attention to a good view, and as if the verses of the Qur'an are explained to these people because they are the people who benefit from it, and focus on remembering and studying it. Some opinions state that the word is related to the word عَرَبِّيَّ meaning to the Qur'an made in Arabic for people who know its words and ensure that nothing comes out of Arabic. ${ }^{64}$ While al-Baida $\bar{a} w \bar{i}$ interpreted phrase لََوْم يَعْمَلَمُونَ as people who are fluent in Arabic and Science.65

The word knowing (يَعْلَمُون) in surah al-Fuṣsilat indicates the enforcement that the Arabic language is the key to disseminate the information and knowledge contained in the Qur'an. As it is known that the Qur'an is the main source of Islamic progress and the evolution of the formation of Islamic science, around the first hundred years of the migration which had a close relationship with the epistemology of Islamic studies. The Qur'an encourages Muslims to seek knowledge, learn, analyze, and use common sense as much as possible for its benefit. ${ }^{66}$ Al-Quran is a source of knowledge, not only in the form of the Qur'an but in the form of the Qur'an in Arabic with the words Qur'anan 'Arabiyyan, as emphasized in Surah alNahl with the words arabiyyun mubin which means clear Arabic.

\section{Encouraging to Think (لََُلَّكُمْ تَعْقِلُون)}

In the Qur'an, there are two verses that emphasize the intelligent function of the Qur' an in Arabic, namely: the word of Allah swt. in QS Yusuf/12: 1-2 and QS al-

${ }^{63}$ Al-Mamlakah al-‘Arabiyah Al-Sa'ūdiyyah, Tafsir al-Muyassar (Cet. II; Saudi: Majma’u alMalik Fahd li Ṭabā' at al-Mushaf al-Syarif, 2009), p. 477.

${ }^{64}$ bin 'Abd al-Rahmān bin Tamām bin'Ạtiyah Abu Muhammad 'Abd al-Haq bin Gālib, alMuharrar al-Wajīz fí Tafsìr al-Kitāb al- 'Azīz, Juz V (Beirut: Dār al-Kutub al-'ilmiyyah, 2001), p. 4.

${ }^{65}$ Nasiruddin al-Baiḍāwī, Anwār al-Tanzīl wa Asrār al-Ta’wìl, Juz V (Beirut: Dār Ihyā' alTurāis al-'Arabi, 1997), p. 66.

${ }^{66}$ Ziauddin Sardar, Explorations In Islamic Science (London \& New York: Mansell Publishing Limited, 1989), p. 1. 
Zukhruf / 43: 1 -3 which the two verses end with the lafaz لعَََّكُمْ تَعْقِلُون. As for the word of Allah in QS Yusuf/ 12: 1-2:

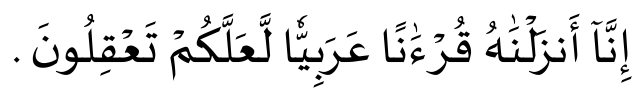

Translation:

"In fact, We sent it down in the form of the Qur'an in Arabic, so that you can understand it."

QS al-Zukhruf (43):1-3

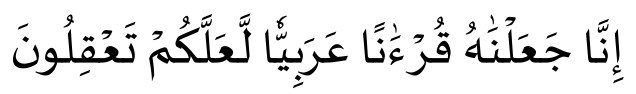

Translation:

"Actually, we have made the Qur'an in Arabic, that you may understand (it)."

Lafaz لَّعَلَّكُمْ تَعْقِلُونَن in the two verses above means so that you know the meaning contained there in. Arabians understand the word hَ لَعَّ has a similar meaning to عسى, and the letter $J$ is zá'idah which is taukid that means emphasis or affirmation. So, it means it is a hope for them to study it. ${ }^{67}$ While al-Baida $\bar{a} w \bar{i}$ understood the lafaz لَعَلَكُحْ تَعْقِلُونَ as the reason for why the Qur'an was revealed as a reading using your language (the Arabs) so that you understand it and master its meaning by using sense and mind, then study it. Thus, those who have not studied yet stories as miracles, cannot describe but imagine it. ${ }^{68}$ Al-Baida $\bar{a} \bar{i}$ means the

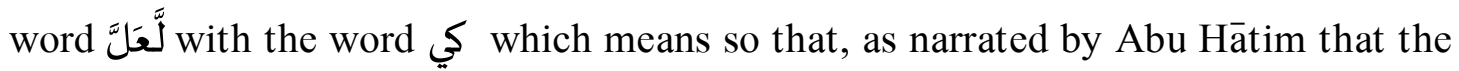

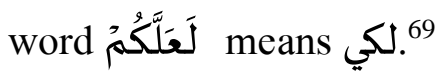

The word 'aqala which is used in the two verses above is the form of the verb or fi'il Mudäri' which means an activity which is in a continuous process. The word intelligent means less ignorance, or knowing from the unknown. ${ }^{70}$ So, almost all the interpreters or mufassir translate the word لَعَلَّكُمَ تَعْقِلُونَ as "so that you understand". The process of thinking and eliminating ignorance is an effort and finally comes to the stage of understanding.

${ }^{67}$ Syamsuddin al-Qurtubī, Tafsìir Al-Qurtubī, Juz IX (Cairo: Dār al-Kutub al-Miṣriyyah, 1964), p. 119.

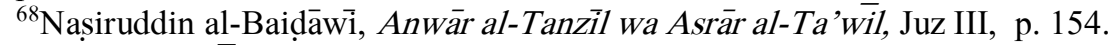

${ }^{69}$ Ibnu Abì Hātim Al-Rāzì, Tafsìr al-Qur'ān al-'Azịm li Ibnu Abi Hātim, Juz VII (Saudi: Maktabah Nazār Muṣtāfā al-Bāz, 1998), p. 2099.

${ }^{70}$ Ahmad bin făris bin Zakariya, Maqāyis al-Lugah, Juz IV (Beirut: Dār al-Fikr, 1979), p. 69. 
From the research results, the word al-Qur'an is repeated 70 times in the Qur'an, only 2 verses are connected with the word لعَلَّكُمْ تَحققُلُونَ, and both are phrase قُرْرَانًَا عَرَبِيّا using Arabic as miracles by the linguistic side encourages people to continue thinking and studying the Qur'an's meaning behind its Arabic text. The Qur'an has made Arabic as a medium to explore its meaning, so it is not wrong to say that the existence of Arabic as the language of the Qur'an encourages people to think.

\section{Encouraging Spirituality (لَعَلَّهُم يَتََّقُونَ)}

The urgency of Arabic as an encouragement to spirituality can be seen in the word of Allah in QS al-Zumar/ 39: 27-28 and QS T⿳亠丷⿵冂丶 discuss the revelation of the Qur'an in Arabic, then, they ended with the lafaz لَعَلَّهُمْ which means that you are cautious. QS al-Zumar / 39: 27-28

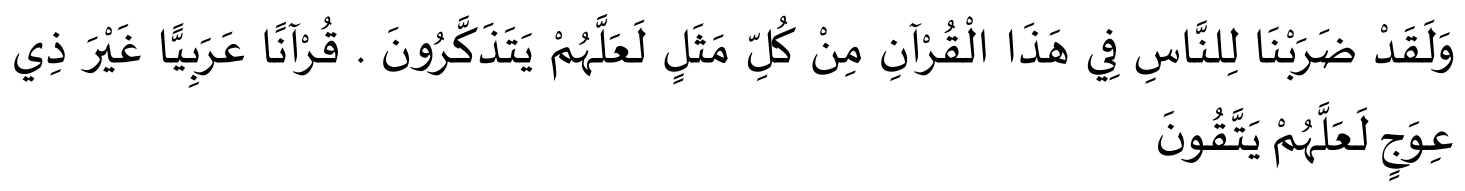

Translation:

"And indeed we have made in this Qur'an all kinds of parables for mankind so that they may learn, that is, the Qur'an in Arabic there is no bend (in it) so that they may fear."

QS Tăhāa/20:113

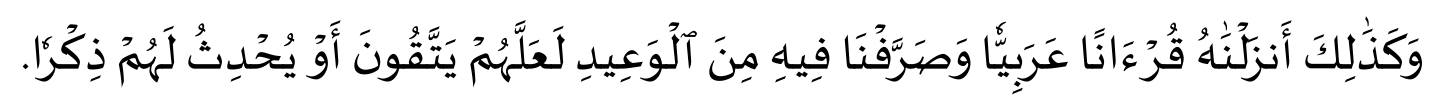

Translation:

"And thus We have sent it down as an Arabic Qur'an and have diversified therein the warnings that perhaps they will avoid [sin] or it would cause them remembrance."

These two verses end with the words لَعَلَّهُهْ يَتَّقُونَ which contains the meaning of the purpose for which he delivered the verse. According to al-Tabara $\bar{i}$, what is meant by لَعَلَّهُهْ يَتَّقُونَ is that they understand the message conveyed by Allah in the Qur'an so that they fear what Allah warns of all His power and bring it to worship and acknowledge the oneness of Allah and leave other than Him. ${ }^{71}$ Taqwa is the purpose of all human worship. It can be seen how the verses of Allah in the Qur'an

\footnotetext{
${ }^{71}$ Al-Ṭabārì, Jāmi' al-Bayān fì Ta’'wìl al-Qur'ān, Juz XXI, p. 281.
} 
that explain prayer, fasting, alms giving, and hajj have a very close correlation with taqwa but have a very prior connection because the purpose of four such worship is the attainment of piety. ${ }^{72}$

Another side, Word of Allah in QS al-Syū rā / 42: 7QS al-Syūrā/ 42: 7

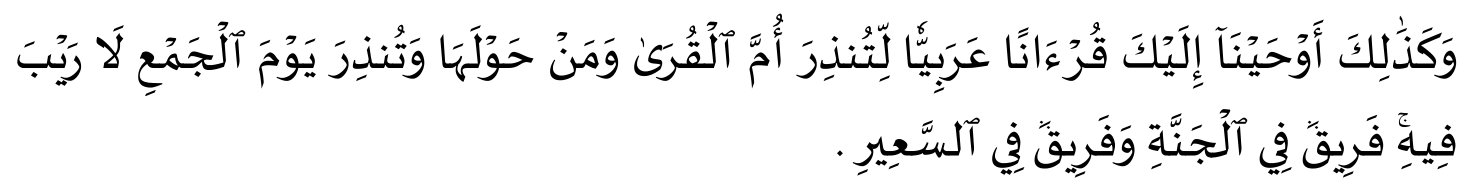

Translation:

"Thus, do We reveal to you the Qur'an in Arabic, so that you may warn the ummul Quran (the people of Mecca) and the people (the states) around it and warn (also) about the Day of Gathering (doomsday) that there is no doubt about it. A party enters heaven, and a party enters Hell."

Word of Allah in the Qur'an Surah al-Ah qā q / 46:12

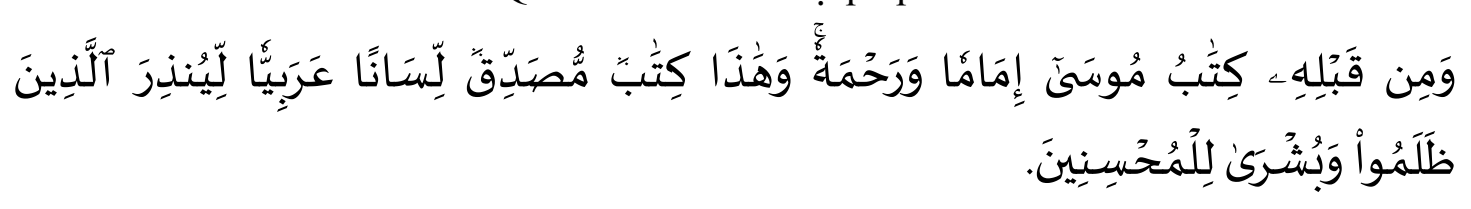

Translation:

"And before the Qur'an, there was the book of Moses as a guide and mercy. And this (Qur'an) is a book that allows it in Arabic to warn the wrongdoers and to give good news to those who do well."

Both of the above verses describe that Allah sent down the Qur'an to Muhammad using the Arabic language because he was sent to the Arabs so that they would understand the meaning of Allah and remember it. Indeed, Allah did not send a messenger except in the language of his people, so that he could explain to them the people of Mecca and its surroundings, and reach all mankind about the warning of Allah on the punishment of the wrongdoers and about the good news to those who do well.73 Here it appears that the Qur'an was revealed as a message that carries a warning guide so that mankind can be pious to abandon what is forbidden and carry out all his commands. However, all of that can be understood best if you understand the Qur'an in Arabic. The emphasis of the above verses is that the Qur'an in Arabic was revealed so that they could understand its contents. This indirectly makes Arabic as one of the keys to the path of piety to God.

${ }^{72}$ Mat Saicho, 'Makna Taqwa dan Urgensitasnya dalam Al-Qur'an', Usrah, vol. 3. no. 1 (2017), p. 49.

${ }^{73}$ Abu Ja'far al-Ṭabāri. Jāmi’ al-Bayān fì Tafsìir al-Qur'ān. Juz XXI, p. 109. 


\section{E. Conclusion}

The study on this paper includes the following points:

1. It is clearly that Arabic in the Qur'an is Arabic that had been agreed upon by the Arabs as their language. They understood Arabic as a language and it had been popularly used among the Arabs and pronounced clearly and fluently when the Qur'an was revealed. The diction used to represent the Arabic term in the Qur'an is the word عربيّي which is adjective (șifat) that connects to word Qur'añ, lisā n, and hukman.

2. The existence of Arabic mentioned in the Qur'an are: a) Arabic is a fluent and clear language, that is, Arabic fushah which is understood by all Arabs, and it does not mix with a foreign language or 'ajam language which is not understood by Arabs. b) the Arabic language of the Qur'an is a Miracle, with a very beautiful style of language and it amazed the Arabs who at that time were very interested in poetry and literature; c) and Arabic as a language syariah/law, means that the Qur'an was revealed concerning to the condition of the Arabs at that time and used the Arabic to facilitate them in understanding the laws and regulations mentioned in the Qur'an. Meanwhile, for non-Arabic people, Arabic is one of the tools that must be mastered properly so that they can understand the content of sharia law holistically and keep away from misunderstanding the law.

3. The urgencies of the Arabic in the Qur'an are the key to understand the Qur'an, encouraging thinking, and encouraginh spiritual direction.

\section{BIBLIOGRAPHY}

Abu Muhammad 'Abd al-Haq bin Gālib, bin 'Abd al-Rahmān bin Tamām bin'Atiyah. al-Muharrar al-Wajiz fi Tafsir al-Kitāb al-'Azíz. Juz V. Beirut: Dār al-Kutub al-'ilmiyyah, 2001.

Al-Bagawī, Abu Muhammad. Ma'ālim al-Tanzīl fi Tafsìr al-Qur'an: Tafsìr AlBagawi. Juz III. Beirut: Dār Ihỵā al Turas al-`Arabiy, 1999.

, Ma'ālim al-Tanzìl fi Tafsìr al-Qur'an: Tafsìr al-Bagawì. Juz IV. Beirut: Dār Ihyā al Turas al-'Arabiy, 1999.

Al-Baiḍ̄àì, Nașiruddin. Anwār al-Tanzīl wa Asrār al-Ta’wìil. Juz V. Beirut: Dār Ihyā' al-Turāis al-'Arabī, 1997. 
Al-Ḍad, Ibrāhīm Muhammad. Muhadharāt fī Tärikkh al-Adab al-'Arabī 'Ashr Sadri al-Islām. Cairo: Al-Azhar, Jāmi'at, 2004.

Al-Hāsyimì, Aḥmad. Jawāhir al-Balāgah fi al-Ma'ānì, wa al-Bayāni, wa al-Badì'i. Jakarta: Maktabah Dār Ihyā al-Kutub al-'Arabiyyah, 1960.

Al-Manzuūr, Ibn Lisān al-’Arab. Cairo: Dār al-Ma'ārif.

Al-Marāgì, Ahmad bin Muștafa. Tafsìi al-Marāgi. Juz XIII. Muṣtafā al-Bābī al-Ḥalbī wa Aulāduhū bi Miṣr, 1946.

Al-Naḥhạas, Abu Ja'far. I'rab al-Qur'ān. Juz II. Beirut: Dār al-Kutub al-'Ilmiyyah, 2000.

Al-Naisabūri, Abu Hasan 'Āli bin Ahmad. Asbāb Nuzūl al-Qur'ān. Cet. III. Dār alIṣlāh, 1992.

Al-Rāgib al-Asfahāni. Mu'jam Mufradāt Alfăz al-Qur'an. Damaskus: Dār al-Qalām, 2009.

Al-Rāzì, Ibnu Abī Hatim. Tafsìir al-Qur'ān al-'Azìim li Ibnu Abi Hātim. Juz VII. Saudi: Maktabah Nazār Muṣtāfāa al-Bāz, 1998.

Al-Rāzi, Fakhruddin. Mafătih al-Gaib. Juz XX. Beirut: Dār Ihyāa al-Turāśs al-'Arabi.

Al-Sa'ūdiyyah, Al-Mamlakah al-'Arabiyah. Tafsir al-Muyassar. Saudi: Majma'u alMalik Fahd li Ṭabā'at al-Mushaf al-Syarif, 2009.

Al-Suyūțì, Jalāl al-Dīn 'Abd al-Raḥmān Ibn Abī Bakr. Al-Itqān fi Ulūm al-Qur'ān. Beirut: Dār al-Kitāb al-'Arabiy, 2003.

Al-Sya'rāwi, Muhammad Mutawalli. Tafsìr Al-Sya'rāwi. Mutāài' Akhbār al-Yaūm, 1997.

Al-Ṭabāri, Abu Ja'far. Jāmi' al-Bayān fì Ta'wìl al-Qur'ān. Juz XXI. Muassasah alRisālah, 2000.

—_. Jāmi' Al-Bayān FīTa’wīl Al-Qur'ān. Juz XVII. Muassasah al-Risālah, 2000.

Al-Ṭayyâr, Musā'id bin Sulaimān Ibnu Nāsir. Tafsīir Al-Lughawi Li Al-Qur’ān AlKarim. Arab Saudi: Dār Ibnu Jauzi.

Al-Zamakhsyarīi, Abu al-Qāsim Mạ̣mūd Ibn Amr ibn Aḥmad. Al-Kasysyāf 'an Haqāiq Gawāmiḍ al-Tanzīl. Juz IV. Beirut: Dār al-Kutub al-'Arabi, 1986.

Al-Zarqāni, Muhammad 'Abd al-'Aẓim. Manāhil al-'Irfān fì 'Ulūm al-Qur'an. Mesir: Dār al-Iḥyā.

Bāqi, Muhammad Fuad Abdul. Mu'jam al-Mufahras li Alfäz al-Qur'ān al-Kan̄m. Cairo: Dār al-Ḥadīṣ, 2007.

Elias, Elias A. Modern Dictionary: Arabic-English. Beirut: Dār al-Jail, 1972. 
Hanbal, Abu Abdullah Ahmad bin Muhammad bin. Musnad Al-Imam Ahmad Bin Hanbal. XXXV. Muassasah Risālah, 2001.

Kas̄ìr, Abu al-FaḍāI Ismā'îl bin Umar bin. Tafsir al-Qur'ān Al-'Azīim. Juz IV. Dār Tayyibah li al-Nasyr wa al-Tauzì', 1999.

Khalid, M. Rusydi. 'Metodologi Kitab Ma'ālim al-Tanzīl Karya Al-Bagawiy'. Adabiyah, vol. 17. no. 2 (2017).

Mat Saicho, Usrah. 'Makna Taqwa dan Urgensitasnya dalam Al-Qur'an'. vol. 3. no. 1 (2017).

Muhammad Idrīs al-Syāfi'i. al-Risālah, ed. by Ahmad Muhammad Syakir. Beirut: al-Maktabah al-'Ilmiyah.

http://www.shamela.ws [accessed 2 June 2020]

https://quran.com/26 [accessed 12 June 2020]

https://quran.com/13 [accessed 12 June 2020]

https://quran.com/12 [accessed 12 June 2020]

https://quran.com/13 [accessed 12 June 2020]

https://quran.com/16 [accessed 12 June 2020]

https://quran.com/39 [accessed 12 June 2020]

https://quran.com/4I [accessed 12 June 2020]

https://quran.com/14 [accessed 12 June 2020]

https://quran.com/20 [accessed 12 June 2020]

https://quran.com/42 [accessed 12 June 2020]

https://quran.com/43 [accessed 12 June 2020]

https://quran.com/46 [accessed 12 June 2020]

Noldeke, Theodore, Sketches from Eastern History Terj. John Suterland Black, M.A. London: Darft Publishers Limited, 1985.

Muhammad Mutawalli al-Sya'rāwi, 'Tafsīr Al-Sya'rāwi' ${ }^{-}$http://www.shamela.ws̄ [accessed 2 June 2020]

Qutub, Sayyid. Taswìr al-Fanny fi al-Qur'ān. Beirut: Dār al Syurūq.

Rippin, Andrew. Introduction to The Qur'an: Style and Contents. Hampshire: Ashgate Publishing Limited, 2001.

Sardar, Ziauddin. Explorations in Islamic Science. London \& New York: Mansell Publishing Limited, 1989. 
Shihab, M. Quraish. Mukjizat Al-Qur'an. Mizan Pustaka, 1997.

Syamsuddin al-Qurtubī. Tafsìr Al-Qurtubī. Juz IX. Cairo: Dār al-Kutub alMisriyyah, 1964.

Syamsuddin Arif. Al-Qur'an dan Diabolisme Pemikiran. Jakarta: Gema Insani Press, 2007.

Zakariya, Ahmad bin fāris bin. Maqāyis Al-Lugah. Juz IV. Beirut: Dār al-Fikr, 1979. 


\section{Guidelines}

\section{Submission of Article}

urnal Adabiyah welcomes the articles submission with the main themes on Humanities and Islamic Studies with the emphasis on interdisciplinary and intertextuality approach. Adabiyah is thematicly published twice in a year. ie the theme of the humanities in June and the Islamic Study in December.

Themes related to Islamic Studies are textual studies, scriptural traditions, Islamic law, and theology; and those related to Humanities are language, literature, history, and culture. This scholarly journal Guarantees that the editor decision based on the peer review results will not exceed 30 days from the paper submission date.

Authors are invited to read our archives; to find the relevant topics for the journal, and to submit complete unpublished scientific researches, which are not under review in any other conferences or academic journal.

\section{PUBLICATION ETHIC}

Publication Ethic and Malpractice Statement

Jurnal Adabiyah is a peer-reviewed journal, published twice a year by the Faculty of Adab and Humaniora, Alauddin State Islamic University of Makassar Indonesia. It is available online as open access sources as well as in print. This statement clarifies ethical behaviour of all parties involved in the act of publishing an article in this journal, including the author, the editor-in-chief, the Editorial Board, the reviewers, and the publisher. This statement is based on COPE's Best Practice Guidelines for Journal Editors.

Ethical Guideline for Journal Publication

The publication of an article in Jurnal Adabiyah, is an essential building block in the development of a coherent and respected network of knowledge. It is a direct reflection of the quality of the work of the authors and the institutions that support them. Peer-reviewed articles support and embody the scientific methods. It is therefore important to agree upon standards of expected ethical behavior for all parties involved in the act of publishing: the author, the editor, the reviewer, the publisher, and the society. As the publisher of Jurnal Adabiyah, the Faculty of Adab and Humaniora takes its duties of guardianship over all stages of publishing seriously and it recognizes its ethical and other responsibilities. The Faculty of Adab and Humaniora committed to ensuring that advertising, reprint or other commercial revenue has no impact or influence on editorial decisions.

\section{Publication Decisions}

The editors of Jurnal Adabiyah is responsible for deciding which articles submitted to the journal should be published. The validation of the work in question and its importance to researchers and readers must always drive such decisions. The editors may be guided by the policies of the journal's editorial board and constrained by such legal requirements as shall then be in force regarding libel, copyright infringement, and plagiarism. The editors may confer with other editors or reviewers in making their decisions.

\section{Plagiarism Screening}

It is basically author's duty to only submit a manuscript that is free from plagiarism and academically malpractices. The editor, however, will check all submitted papers through Turnitin.

\section{Fair Play}

An editor at any time evaluates manuscripts for their intellectual content without regard to race, gender, sexual orientation, religious belief, ethnic origin, citizenship, or political philosophy of the authors. 


\section{Confidentiality}

The editors and any editorial staff must not disclose any information about a submitted manuscript to anyone other than the corresponding author, reviewers, potential reviewers, other editorial advisers, and the publisher, as appropriate.

\section{Disclosure and Conflicts of Interest}

Unpublished materials disclosed in a submitted manuscript must not be used in editors' own research without the express written consent of the author.

\section{DUTIES OF AUTHORS}

\section{Reporting Standards}

Authors of reports of original research should present an accurate account of the work performed as well as an objective discussion of its significance. Underlying data should be represented accurately in the paper. A paper should contain sufficient detail and references to permit others to replicate the work. Fraudulent or knowingly inaccurate statements constitute unethical behaviour and are unacceptable.

\section{Originality and Plagiarism}

The authors should ensure that they have written entirely original works, and if the authors have used the work and/or words of others that this has been appropriately cited or quoted.

\section{Multiple, Redundant, or Concurrent Publication}

An author should not in general publish manuscripts describing essentially the same research in more than one journal or primary publication. Submitting the same manuscript to more than one journal concurrently constitutes unethical publishing behaviour and is unacceptable.

\section{Acknowledgement of Sources}

Proper acknowledgment of the work of others must always be given. Authors should cite publications that have been influential in determining the nature of the reported work.

\section{Authorship of the Paper}

Authorship should be limited to those who have made a significant contribution to the conception, design, execution, or interpretation of the reported research. All those who have made significant contributions should be listed as co-authors. Where there are others who have participated in certain substantive aspects of the research project, they should be acknowledged or listed as contributors. The corresponding author should ensure that all appropriate co-authors and no inappropriate co-authors are included on the paper, and that all co-authors have seen and approved the final version of the paper and have agreed to its submission for publication.

\section{Disclosure and Conflicts of Interest}

All authors should disclose in their manuscript any financial or other substantive conflict of interest that might be construed to influence the results or interpretation of their manuscript. All sources of financial support for the project should be disclosed.

\section{Fundamental errors in Published Works}

When an author discovers a significant error or inaccuracy in his/her own published work, it is the author's obligation to promptly notify the journal editor or publisher and cooperate with the editor to retract or correct the paper.

\section{PLAGIARISM}

It is basically author's duty to only submit a manuscript that is free from plagiarism and academically malpractices. The editor, however, will check all submitted papers through Turnitin. 


\section{AUTHOR GUIDELINES}

\section{Guidelines for online submission:}

1. Author should first register as Author to the website of Jurnal Adabiyah. Click the menu "register" to register as an author.

2. Once after the author is registered, please login to the website of Jurnal Adabiyah and submit the article through online submission (with the stat us of active submissions).

3. The article should follow the standard template of Jurnal Adabiyah provided in the website.

4. The citation and bibliography should follow the Turabian citation style.

5. Author is restricted not to send his/her article to another journal before having confirmation from the editorial team (approximately 4 weeks right after the article submitted).

6. Author should follow editorial decisions and recommendations related to the article completion. All reviews and assessements will be informed through online submission.

Article submitted to Jurnal Adabiyah editorial board must follow these guidelines:

1. Article should be based on the scientific research in the field humanities and Islamic studies;

2. Article must be an original work and has not been previously published;

3. Article should be written in Arabic or English languages;

4. Article must be typed in one-half spaced on A4-paper size;

5. Article's length is about $6,000-10,000$ words;

6. All submission must include a 150-250 word abstract;

7. Abstract should be written in 3 languages; Arabic, English, and Bahasa;

8. Full name(s) of the author(s) must be stated, along with his/her/their institution and complete address;

9. All submission should be in OpenOffice, Microsoft Word, RTF, or WordPerfect document file format;

10. Bibliographical reference must be noted in footnote and bibliography according to Jurnal Adabiyah style. In addition, it is suggested for author(s) to use reference manager tools such

\section{as MENDELEY or 7 otero}

When a source is cited for the first time, full information is provided: full name(s) of author(s), title of the source in italic, place of publication, publishing company, date of publication, and the precise page that is cited. For the following citations of the same source, list the author's last name, two or three words of the title, and the specific page number(s). The word ibid., op.cit., and loc.cit. are may not be used any more.

\section{Example in footnotes:}

${ }^{1}$ Mircea Eliade (ed.), The Encyclopedia of Religion, vol. 8 (New York: Simon and Schuster, 1995), h. 18.

${ }^{2}$ Norman Daniel, Islam and the West (Oxford: One World Publications, 1991), h. 190.

${ }^{3}$ Syeikh Ja'far Subhāni, Mafăhim Al-Qur'ān (Beirut: Mu'assasah Al-Tarīkh Al-'Arabī, 2010)., Juz 5, h. 231. 
${ }^{4}$ Syeikh Ja'far Subhānī, Mafāhim Al-Qur'ān, h. 8-9.

\section{Example in bibliography:}

Subhānī, Syeikh Ja'far. Mafăhim Al-Qur'ān. Beirut: Mu'assasah Al-Tarīkh Al-’Arabī, 2010.

Eliade, Mircea (ed.). The Encyclopedia of Religion, vol. 8. New York: Simon and Schuster, 1995.

Daniel, Norman. Islam and the West. Oxford: One World Publications, 1991.

Shihab, Muhammad Quraish. Sunnah-Syiah Bergandengan Tangan: Mungkinkah? Kajian Atas Konsep Ajaran Dan Pemikiran. Cet. III. Jakarta: Lentera Hati, 2007.

\section{Detail informations of the footnotes:}

1. Holy book

Al-Qur'ân, Al-Baqarah/2: 185.

Perjanjian Baru, Mrk. 2: 18.

2. Qur'anic translation

${ }^{1}$ Departemen Agama RI, al-Qur'an dan Terjemahannya (Jakarta: Darus Sunnah, 2005), h. 55.

3. Book

${ }^{1}$ Muḥammad 'Ajjaj al-Khațib, Ușl al-Hadith: 'Ulumuh wa Mușțalaḥ uh (Beirut: Dâr al-Fikr, 1989), h. 57.

4. Translation Books

${ }^{1}$ Toshihiko Izutsu, Relasi Tuhan dan Manusia: Pendekatan Semantik terhadap al-Qur'an, terj. Agus Fahri Husein dkk (Yogyakarta: Tiara Wacana, 2003), h. 14.

5. Voluminous book

${ }^{1}$ Muḥammad al-Ṭâhir b. 'Ashur, al-Tahrīir wa al-Tanwīr, Vol. 25 (Tunisia: Dâr al-Suhûn, 2009), h. 76.

${ }^{1}$ Muḥammad b. Ismā‘īl al-Bukharī, al-Jami‘ al-Ṣaḥịh, Vol. 2 (Beirut: Dar al-Kutub al-‘Ilmı́yah, 1999), h. 77.

6. Article in book

${ }^{1}$ Sahiron Syamsuddin, "Metode Intratekstualitas Muhammad Shahrur dalam Penafsiran al-Qur'an" dalam Abdul Mustaqim dan Sahiron Syamsuddin (eds.), Studi al-Qur'an Kontemporer: Wacana Baru Berbagai Metodologi Tafsir (Yogyakarta: Tiara Wacana, 2002), h. 139.

7. Article in encyclopaedia

${ }^{1}$ M. Th. Houtsma, "Kufr" dalam A. J. Wensinck, at al. (ed.), First Encyclopaedia of Islam, Vol. 6 (Leiden: E.J. Brill, 1987), h. 244.

8. Article in journal

${ }^{1}$ Muhammad Adlin Sila, "The Festivity of Maulid Nabi in Cikoang, South Sulawesi: Between Remembering and Exaggerating the Spirit of Prophet", Studia Islamika 8, no. 3 (2001): h. 9.

9. Article in mass media

${ }^{1}$ Masdar F. Mas'udi, "Hubungan Agama dan Negara”, Kompas, 7 Agustus 2002. 
10. Article in Internet

${ }^{1}$ Muhammad Shahrūr, "Reading the Religious Teks: a New Approach" dalam http://www.shahrour.org/25 Februari 2010/diakses 5 Juni 2010.

11. Thesis or dissertation

${ }^{1}$ Syahruddin Usman, "KinerjaGuru Penddikan Agama Islam pada SMAN dan SMKN Kota Makassar”, Disertasi (Makassar: PPs UIN Alauddin, 2010), h. 200.

\section{COPYRIGHT NOTICE}

Authors who publish with this journal agree to the following terms:

1) Authors retain copyright and grant the journal right of first publication with the work simultaneously licensed under a Creative Commons Attribution License that allows others to share the work with an acknowledgement of the work's authorship and initial publication in this journal.

2) Authors are able to enter into separate, additional contractual arrangements for the non-exclusive distribution of the journal's published version of the work (e.g., post it to an institutional repository or publish it in a book), with an acknowledgement of its initial publication in this journal.

3)Authors are permitted and encouraged to post their work online (e.g., in institutional repositories or on their website) prior to and during the submission process, as it can lead to productive exchanges, as well as earlier and greater citation of published work (See The Effect of Open Access). 